\title{
No effect of anthropogenic food provisioning and population density on the aggressive behavior of a territorial Cichlid: a case study
}

\author{
Rayan Amorim Pereira ${ }^{1}$ \\ Eduardo Bessa ${ }^{1,2 *}$ \\ ${ }^{1}$ University of Brasília, Campus Planaltina, Área Universitária 1 \\ Vila N. Sra. De Fátima, CEP 73.380-900, Planaltina - DF, Brazil \\ ${ }^{2}$ Programa de Pós-graduação em Ecologia, Universidade de Brasília - DF, Brazil \\ * Corresponding author \\ profbessa@unb.com
}

Submetido em 25/10/2021

Aceito para publicação em 04/02/2022

\section{Resumo}

Efeito nulo do provisionamento antropogênico de alimento e da densidade populacional no comportamento agressivo de um ciclídeo territorial: um estudo de caso. A oferta de alimentos para peixes é uma atividade de lazer muito comum, especialmente em atrações turísticas, causando impactos que ainda são pouco compreendidos. Existem muitas espécies de peixes territoriais para as quais a disponibilidade de energia pode limitar a agressividade e o crescimento populacional. Nosso estudo de caso avaliou se o provisionamento de alimentos e o adensamento populacional resultante modificam o comportamento agressivo em um ciclídeo territorial, a tilápia do Congo (Tilapia rendalli). Comparamos a agressividade entre uma população que recebe grandes quantidades de alimento e tem alta densidade e uma não alimentada e de baixa densidade. A agressividade foi igual entre grupos provisionados e não provisionados, exceto quando oferecemos alimentos, o que estimulava a agressão na área não provisionada. A oferta de alimento por humanos e a densidade reduziram a área dos ninhos, mas não aumentaram a agressividade, sugerindo uma possível habituação à presença de conspecíficos e uma redução da agressividade competitiva.

Palavras-chave: Agonismo; Competição; Comportamento animal; Tilapia rendalli; Turismo

\section{Abstract}

Food provisioning for fish is a very common leisure activity, especially in tourist attractions, causing impacts that are still poorly understood. There are many species of territorial fish to whom energy availability can limit aggressiveness and population growth. Our case study evaluated whether food provisioning and the resulting population density modify aggressive behavior in a territorial cichlid, the Congo tilapia (Tilapia rendalli). We compared the aggressiveness between a population that receives large amounts of food and has high density and an unfed and low-density population. Aggressiveness was the same between provisioned and non-provisioned treatments, except when we offered food, which stimulated aggression in the unprovisioned area. Food provisioning by humans and density reduced nest area, but did not increase aggressiveness, suggesting a possible habituation to the presence of conspecifics and a reduction in competitive aggression.

Key words: Agonism; Animal behavior; Competition; Tilapia rendalli; Tourism 


\section{Introduction}

Feeding fish as a tourism and leisure attraction affects the natural behavior of many species (BESSA; GONÇALVES-DE-FREITAS, 2014). Although there are some situations, for example environments with food shortages or with a lot of competition, in which habitat change reduces food availability and conservation could benefit from food provisioning (EWEN et al., 2015), this is becoming an urgent issue with the growing presence of humans in preserved locations, and the impacts this human-wildlife interaction brings (BLUMSTEIN et al., 2017), including to the aquatic environment. One way sought by people to interact with fish is provisioning them with food, which is often excessive and inadequate (BESSA et al., 2017). The bad quality and large quantity of the food offered by visitors often cause health problems to these fish (LAROCHE et al., 2007). Food provisioning negatively affects fish by reducing health (BROOKHOUSE et al., 2013), altering habitat use (FITZPATRICK et al., 2011; ALBUQUERQUE et al., 2014) and changing population structure (MILAZZO et al., 2005; ILARRI et al., 2008; FEITOSA et al., 2012). It is also possible that food provisioning accelerates fish habituation to humans (GEFFROY et al., 2015), reducing escape reactions and increasing predation risk (MILAZZO et al., 2006). Many populations, including fish, tend to grow in response to food availability (STENBERGER; GILBERT, 1985; PETRIK et al., 2019), and this bottom-up population control has been shown to be more effective than top-down control by predators in fish (KOKKONEN et al., 2018). Therefore, food offered by humans has a large array of effects on fish, reaching aspects of fish biology still understudied.

Territoriality is the defense of a limited area, within which there is some valuable resource with concentrated distribution, against intra- or interspecific competitors (MAHER; LOTT, 2000). Aggressiveness, either indirect (sequential behavior that uses visual, acoustic and chemical cues to threat without direct contact) or direct (physical aggressiveness, which causes damage to the body), is often applied to territorial defense (ROS et al., 2006). Aggressiveness is a time-consuming and costly activity in terms of energy expenses (GILL;
WOLF, 1975), predation risk (MAGNHAGEN, 1995; CANDOLIN; VOIGT, 2001) and increase in parasite load (CAVALHEIRO; BESSA, 2016). Therefore, territory size and territorial aggression should be limited by food and energy availability, especially if the territory does not provide, or even limits, access to food.

Cichlids are freshwater fishes (FELDBERG et al., 2003) who defend reproductive territories with strong aggression (KULLANDER, 1998). They are mostly diurnal with intense and complex parental care (KEENLEYSIDE, 1991). Such characteristics make the Cichlids good models to study the effects of feeding on aggressiveness. The Congo tilapia (Tilapia rendalli) is a generalist and invasive Cichlid, which adapts easily to different environments (LAZZARO, 1991). Such species also has some similarities with reef species targeted by tourism and fish feeding, with phylogenetic relatedness and ecological similarities, such as many damselfishes (WESTNEAT; ALFARO, 2005), allowing us to make parallels between freshwater and reef ecosystems where divers or snorkelers feed fish.

Since fish will have more energy to invest in displays (indirect aggression) and fights (direct aggression), food provisioning could increase territorial aggression, especially if the territory does not include a food resource. Thus, the provision of supplemental food would increase fish aggression, as fish would have more access to food and, therefore, more energy available to invest in defending the territory. How population density and energy availability interact is poorly understood thus far and few studies have investigated how food provisioning affect fish behavior (BROOKHOUSE et al., 2013). Here we aim to identify if supplementary food and population density affect territory size and aggressiveness in Congo tilapia populations. This case study was carried out in an artificial environment, which has two lakes with natural substrate, one holding more tilapias that continuously received large amounts of food, and another with fewer tilapias in which the fish could only rely on natural sources of food, such as insects, algae, microcrustaceans, and roots and leaves of Typhonodorum lindleyanum. Our initial prediction was that supplementary feeding and population density would increase aggression in two complementary 
ways, i) by increasing territory and nest size, and ii) by providing more energy for territorial disputes.

\section{Material and Methods}

\section{Model species and study area}

The Congo tilapia (Tilapia rendalli) we used reach as much as $45 \mathrm{~cm}$ in standard length and $2.5 \mathrm{~kg}$ (BOULENGER, 1897), inhabiting warm lenthic water bodies (CAULTON, 1977). Adults reach sexual maturity after six months, when males dig bowl nests on clay, sand or gravel substrate (BOULENGER, 1897), spawning in them (RIBBINK et al., 1981). Adult tilapias protect first the eggs and then the fry for as long as one month after hatching (BALSHINE; BUSTUN, 2008) with fry as large as $4 \mathrm{~cm}$ (RIBBINK et al., 1981). The males aggressively defend their nests and territories (RIPLEY; LOBEL, 2005), while the females choose their mate, evaluating territory and nest characteristics (KEENLEYSIDE, 1991). Adults' territories are only reproductive and provide no food, but they tend to stay close to their territories to feed (HERT, 1992).

Our case study was performed in two nearby artificial ponds with around $50 \mathrm{~m}^{2}$, similar in depth $(66 \mathrm{~cm}), \mathrm{pH}$ (7 according to MACHEREY-NAGEL $\mathrm{pH}$ Indicator Test Sticks) volume (33000 L), bottom profile (flat, mostly concrete), turbidity (between 5.6 and 8.5 NTU according to an ISO $2100 \mathrm{P}$ Portable Turbidimeter) and temperature $\left(21^{\circ}-24^{\circ} \mathrm{C}\right.$, fully exposed to the sun), located in Brasília, Brazil (Lat. 1545'50"S, Long. $47^{\circ} 51$ ' 57 'W). Both ponds have a concrete bottom, but contain three submerged gardens each, with Typhonodorum lindleyanum and Nymphaea sp. plants. The areas of the gardens are similar $\left(2.70 \mathrm{~m}^{2}\right)$ filled with silt, in which introduced tilapias defend territories and build nests.

Congo tilapia's populations were already present in both ponds for more than a decade. Original introduced populations were of similar densities, but later diverged possibly due to the food offering. The Congo tilapias we observed were larger than $15 \mathrm{~cm}$ in total length to avoid sampling juveniles and held nests measuring between 10 and $20 \mathrm{~cm}$ in diameter (see results for more data). Measures were taken with a ruler attached to a rod.

One of the ponds (food provisioned/high-density treatment) is located near a restaurant and receives large amounts of food daily (we estimate it around $1,5 \mathrm{~kg}$ /day provided negligibly by customers throughout the day and abundantly by restaurant staff directly from the kitchen) and sustained a population of $7.8 \pm 1.6$ ind. $\mathrm{m}^{-2}$ (mean $\left.\pm \mathrm{SD}\right)$. Although the other pond is only $23 \mathrm{~m}$ away from the first, we only observed food provisioning there twice during our study, and in a much smaller scale. It also held about one-fourth the population density of the provisioned pond, with $2.1 \pm 1.5$ ind. $\mathrm{m}^{-2}$. The ponds differed in population density ( $t$ test, $t=9.67$, $p<0.0001)$. This unfed and low-density pond constituted our control condition.

\section{Sampling and data analysis}

We calculated the area (A) of each nest considering it as a circle, measuring its diameter $(\varnothing)$ and dividing it by two to have the radius ( $\mathrm{r}$ ) and then using the $\mathrm{A}=\Pi \cdot \mathrm{r}^{2}$ formula. Each nest was considered a sample unit.

Behavioral data were collected between March and May, 2019, adding up to a total of 30 observed days. First, we used direct in situ observations with continuous sampling, to get familiarized with aggressive behaviors and to quantify the frequency of behaviors, and second scan sampling, to evaluate the frequency of aggressive behaviors per session (MARTIN; BATESON, 2007). Each session occurred between $8 \mathrm{~h}$ and $16 \mathrm{~h}$ and lasted for $2 \mathrm{~h}$ for each pond (control and treatment). We quantified the frequency of direct (with contact between individuals) and indirect (no contact) aggressive behaviors in territory-holders based on the behavioral categories described to the Cichlids Cichlasoma dimerus (ALONSO et al., 2011) and Oreochromis niloticus (CARVALHO; GONÇALVES-DE-FREITAS, 2008). A list of the behaviors applied here and their description can be found in the supplementary material (Appendix 1). In accordance with these authors, we considered bites, jaw-locking, attacks from the side, front or back of the contestant as direct aggressions; 
while we considered chasing, frontal and lateral threats as indirect aggression.

After the initial observations based on food offering by the restaurant costumers were finished, we also sporadically offered $500 \mathrm{~g}$ of food (a mixture of seeds, chopped vegetables and Ora-pro-nobis leaves, strawberry and mango) around $14 \mathrm{~h}$, the same period as the typical provisioning by the restaurant. Food was sporadically offered to both the provisioned/high-density and to the control ponds in 16 different days interspaced by at least four days. After that we performed the same 30 repetitions of the 2-h sessions, recording the frequency of aggressive behaviors as described in the previous paragraph. This allowed us to evaluate the effect of occasional feeding on aggressive behavior.

We compared the nest size between the control and treatment ponds using a $t$ test $(\mathrm{N}=58$ nests $)$. Then, we used a Generalized Linear Model to compare the frequency of aggressive behaviors per observation session (sample unit) in relation to three independent variables: type of aggression (direct or indirect), fish density/usual feeding (provisioned or unprovisioned) and sporadic feeding (with or without feeding by the researchers). Although our residuals were normally distributed according to QQ-Plot, overdispersion of the variance data prevented us from using Poisson's distribution. Thus, we fitted our model to a QuasiPoisson's distribution. We applied a critical significance level of $\alpha=0.05$. Descriptive statistics values represent mean \pm standard deviation. All analyses were performed using $\mathrm{R}$ version 4.1.0 ( $\mathrm{R}$ DEVELOPMENT CORE TEAM, 2013) with the function glm in package stats.

\section{Results}

\section{Nest size and fish aggressiveness compared between provisioned/high- density and control ponds}

The unprovisioned pond with lower population density (control) presented larger nests (366.2 \pm $9.07 \mathrm{~cm}^{2}$ ) than the provisioned pond with higher fish density $\left(88.2 \pm 1.13 \mathrm{~cm}^{2}, t\right.$ test, $\mathrm{N}=58, t=3.53$, $p=0.0009)$.

We completed $38 \mathrm{~h}$ of observations. Congo tilapias showed aggressive behavior against conspecifics. Nonetheless, indirect aggression was more frequent than direct aggression $(F=82.861 ; p<0.001$; Table 1$)$. The most frequent aggressive behavior summing both treatment and control ponds was chasing (Figure 1).

Usual anthropogenic food provisioning did not alter the occurrence of aggressive behaviors in tilapias $(F=1.674 ; p=0.198$; Table 1$)$ neither in indirect (Figure 2a) nor in direct aggression (Figure $2 \mathrm{~b}$ ). When we offered the fish sporadic food in both the regularly provisioned/high-density and control ponds, indirect aggression became more frequent in fish from the control pond (Figure 2c), while direct aggression remained the same $(F=194.545 ; p<0.001$; Table 1; Figure 2d).

TABLE 1: Results of the Generalized Linear Model on the frequency of aggressive behavior. DF $=$ degrees of freedom; $F=$ statistical result of the test; $p=$ probability of type I error.

\begin{tabular}{lcccc}
\hline & DF & Deviance residue & $\boldsymbol{F}$ & $\boldsymbol{p}$ \\
\hline Aggression type & 1 & 454.78 & 82.861 & $1.197 \mathrm{e}-15$ \\
Usual provisioning/fish density & 1 & 9.19 & 1.674 & 0.198 \\
Sporadic provisioning & 1 & 1067.74 & 194.545 & $2.2 \mathrm{e}-16$ \\
\hline
\end{tabular}


FIGURE 1: Total number of occurrences of each aggressive behaviors in Tilapia rendalli in both control and treatment ponds (sum). Black bars represent indirect aggression and grey bars direct aggression.

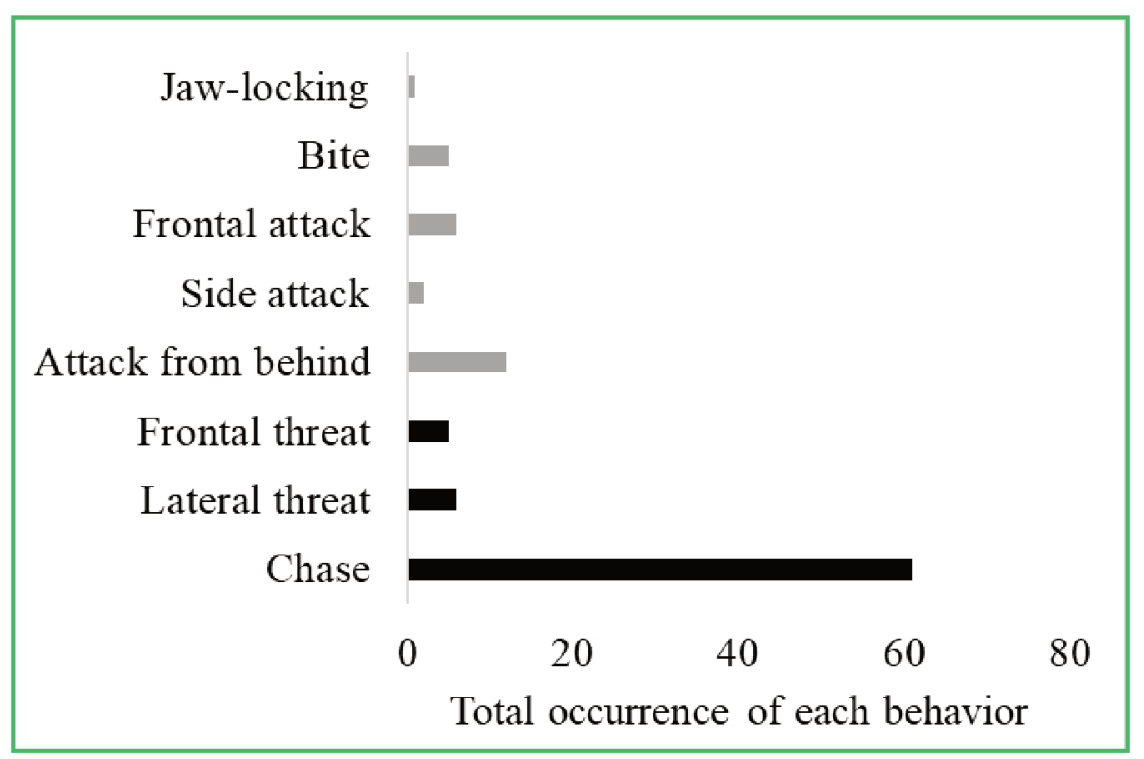

FIGURE 2: Effect of usual food provisioning on (a) indirect aggression, and (b) direct aggression; and effect of sporadic food provisioning by the researchers on (c) indirect and (d) direct aggression in both the treatment (provisioned, high-density) and control (unprovisioned, low-density) ponds. The only difference occurred in indirect aggression when food was sporadically offered. Bars represent means, while whiskers represent standard deviation; * indicates significant difference between control and treatment.

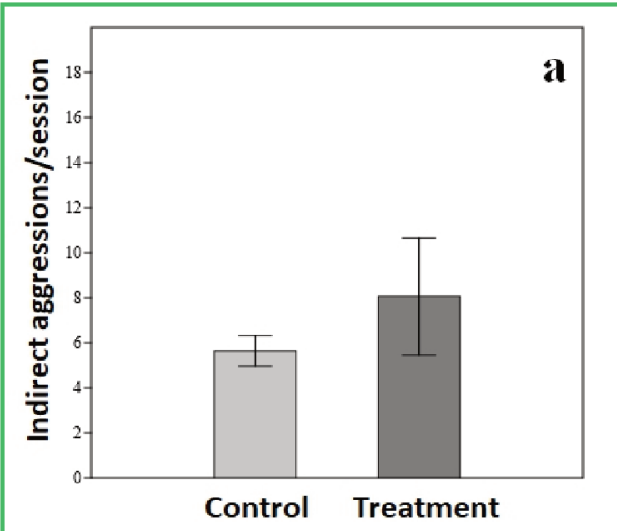

Control Treatment

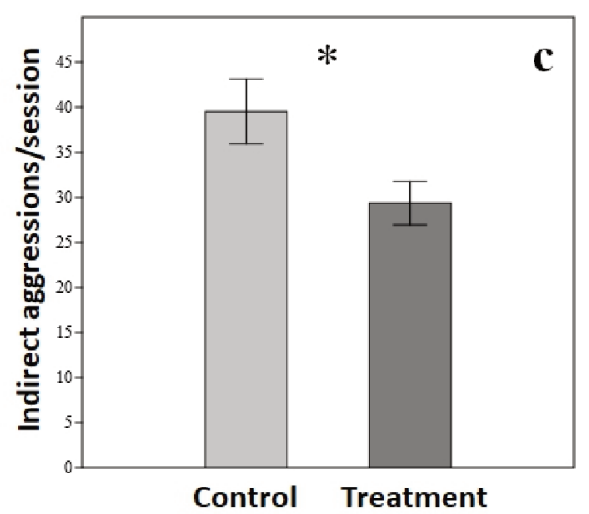

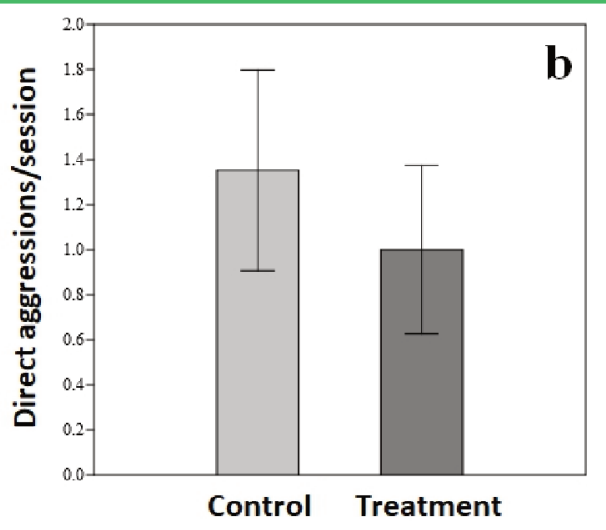

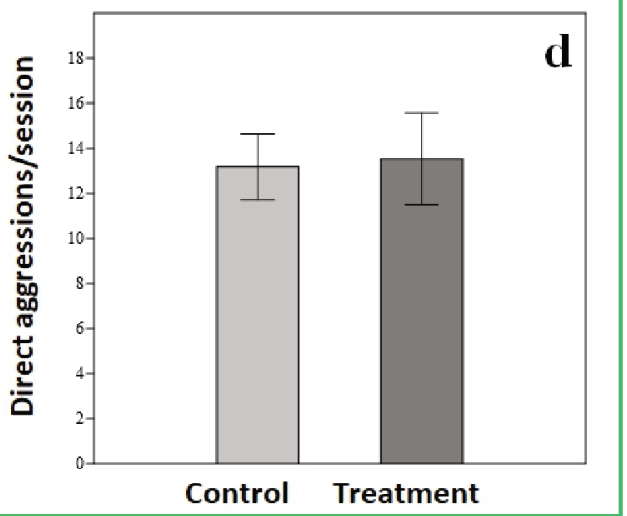




\section{Discussion}

Our study case showed that nest size in Congo tilapia, an admittedly aggressive fish, was lower in the pond with food provisioning and higher population. However, food abundance and fish density did not make these fish more aggressive. On the contrary, the food competition made these animals display more indirect aggression when sporadic food, in this case, a limiting resource, was experimentally delivered by the researchers.

We observed larger nests in the unprovisioned/ lower density control pond. Nests with $20 \mathrm{~cm}$ in diameter, such as we observed, are described for another much smaller Brazilian cichlid, Cichlasoma dimerus (ALONSO et al., 2011). Our results point to a difference in nest size in response to food provisioning and/or population density. The territory and maintenance of nests are part of the reproductive behavior of cichlids, as females select partners with larger territories and better nests (KEENLEYSIDE, 1991). It is noteworthy that, in Congo tilapias, the guarded areas provide males with nest, not food. According to Grant (1997), optimal territorial size is reduced with the presence of numerous competitors, so this could result in proportionally smaller nests. Population density probably constrains nest area in the Congo tilapia.

Tilapias perform around three times more indirect aggressive displays than direct aggression. This is explained by the much higher costs of direct aggressiveness, expected with an escalation of the conflict (O'CONNOR et al., 2015). Game theory based on the hawk-dove game (PARKER, 1984) proposes that, if fight injuries are more costly than the gains from feeding, it is more advantageous to ritualize disputes. In the Midas cichlid (Amphilophus citrinellum) food disputes were often solved by threat displays (BARLOW et al., 1975). Social hierarchy is well known in cichlids and reduces aggression (GONÇALVES-DE-FREITAS et al., 2019), especially if the group is stable and status cues are available (GONÇALVES-DE-FREITAS et al., 2008) such as in our study area. In regularly provisioned environments, animals can wait for future feeding opportunities instead of fighting for food momentarily available (GRAND; GRANT, 1994). Moreover, increased food availability by provisioning may reduce food competition and lower agonistic competition in general.

Aggressiveness did not increase with usual food provisioning and population density in our study. A positive correlation between aggression and both food availability and fish density was expected because of energy availability and the probability of encounters between two individuals (GONÇALVES-DE-FREITAS et al., 2019) and because population density destabilizes social hierarchy in cichlids (LAMBERT; DUTIL, 2001). Other researchers observed reduced aggression in highly dense aquaculture tanks, but this occurred in a less aggressive and non-territorial group, the salmonids, and aggression did increase with food availability (ELLIS et al., 2005; ADAMS et al., 2007). Nevertheless, results consistent with ours were observed previously in Congo tilapia (BHUJEL, 2000). This author reported that, packed in high densities, Congo tilapia reduces aggressiveness counterbalancing density. These data also agree with Schwedler and Johnson (2000), which propose that low population densities stimulate territorial aggression among tilapia. Food availability could also have reduced agonism by affecting competitive aggressiveness, but only if population density did not increase in parallel to food availability and if competition for food was stronger than that over reproductive territories. Grant et al. (2002) reported that food abundance and aggression resulted in a Gaussian graph, with aggressiveness returning to the original levels when food was abundant due to reduced competitive aggression, but this occurred between juveniles with no reproductive territoriality. Our findings that food provisioning and high fish density does not increase aggression contradict our original hypothesis and are somewhat surprising, although some previous studies have anticipated similar results.

Direct and indirect aggressiveness increased more than six times when food was offered sporadically, in the unprovisioned/lower-density control population. Thus, competition for food, not abundant feeding, stimulated indirect aggressiveness. Aggressive competition can 
explain the increase in aggression when sporadic food was delivered to the unprovisioned control pond, but it cannot be accounted for in the provisioned pond if fish population there is proportionally large or if competition over reproductive territories is stronger than that over food. Competitive aggression over food was observed in the Midas cichlids, in which gold juveniles were rarely aggressed when food was abundant (BARLOW et al., 1975) but became harassed by larger juveniles after food deprivation (BARLOW; MCKAYE, 1982). There are other costs to territoriality that could deter aggressiveness besides the energetic ones, such as the risk of predation (CANDOLIN; VOIGT, 2001), and exposure to threats such as divers (BESSA; GONÇALVES-DE-FREITAS, 2014). It may also be that the cost-benefit trade-off of territoriality (HINSCH; KOMDEUR, 2010) in terms of reproductive success is achieved by benefits other than territorial dominance in a food-saturated environment, such as increased female fecundity and nutrient deposition in yolk. A shift in the cost-benefit trade-off in territoriality and reduced competition over food may hinder tilapia aggressiveness in the provisioned and high-density pond.

In our study, feeding did not increase aggression, but excessive food is known to cause water quality loss by $\mathrm{pH}$ and dissolved oxygen reduction and increased ammonia (DE CASTRO et al., 2014). Although feeding is generally described as an impact (BESSA et al., 2017), in scenarios where natural food is being depleted feeding may be considered a conservation strategy (SERESS et al., 2020), as long as it follows quality and quantity guidelines (EWEN et al., 2015). Tilapia are omnivorous and generalist animals (CHERVINSKI, 1982), the trophic level most affected by food provisioning (MEDEIROS et al., 2007; ILARRI et al., 2008). The appropriate level for ingestion of provisioned food is still unknown to many species (DA SILVA et al., 2020).

Some limitations of this research are that the provisioned pond and the denser pond were the same, so it is more difficult to specify which factor influenced our results. While this is true, fish densities were similar when the ponds were first colonized. That suggests that provisioning resulted in higher population densities, allowing us to attribute our main findings to fish feeding, even when it is more related to higher density, because population growth probably results from feeding. During our observations we saw tilapia fingerlings and more nests in the provisioned pond, indicating that population in the provisioned pond was probably still increasing by the time of the experiment. We also evaluated a single pond as control and treatment, although this could result in the lack of study site replications, making ours a study case, we considered as sampling unit each nest (nest diameter) or each observation session (aggressiveness). Generalizations made from this case study to other situations should be made with great caution, due to lack of replication.

Tilapias are not often considered a target species for tourism, but some parallels with tourism sites in which tourists feed fish as a leisure activity can be drawn. There are many destinations where tourists contribute to local economies (GARROD; WILSON, 2004) but offer large amounts of food to the fish (BESSA et al., 2017). Several species in such environments are closely related to tilapias and resemble them ecologically, being highly territorial with demersal habits, omnivorous diet and nesting, such as many pomacentrids (HOSTIMSILVA et al., 2006) and other cichlids (BESSA; GONÇALVES-DE-FREITAS, 2014). Such species may respond to feeding in the same manner as tilapias, with increase in density, smaller nests and altered territorial aggressiveness.

We conclude that anthropogenic food provisioning and high fish density, which is probably a result of the food provisioning, may act by three pathways on the aggressiveness of territorial fish. First, high population density reduces aggression possibly due to habituation to conspecifics. Second, excessive feeding reduces competitive aggression if it overcomes population growth. Third, more food increases aggression by reducing the energetic cost of aggressiveness, while high density increases the chance of aggressive encounters. These opposing effects of food provisioning and density on aggression could cancel one another, avoiding changes in aggression frequency. Future studies should concentrate on untangling energy intake and population density in laboratory conditions to test the 
aforementioned scenario. It would also be important to have more population replicates analyzed to confirm the food provisioning effects we got on population density. Finally, our study did not show evidence that feeding increases aggression, nevertheless, excessive food may result in other problems, such as water-quality loss (DE CASTRO et al., 2014). Thus, we hope our study will increase public awareness, and regulation of fish feeding as a leisure practice.

\section{Acknowledgments}

We would like to thank Fundação Darcy Ribeiro, and its director, Ester Lima, for granting us access to the research site. We also thank Eliane Gonçalves de Freitas, Mariana de Carvalho and Pedro Uchoa Aquino de Podestá for the careful reading and invaluable suggestions on the first drafts of this study, and Diogo Andrade Costa for statistical support. This study was funded by FAP-DF (Process number 24.5.2018).

\section{References}

ADAMS, C. E.; TURNBULL, J.; BELL, A.; BRON, J.; HUNTINGFORD, F. A. Multiple determinants of welfare in farmed fish: stocking density, disturbance, and aggression in Atlantic salmon (Salmo salar). Canadian Journal of Fisheries and Aquatic Sciences, Ottawa, v. 64, n. 2, p. 336-344, 2007.

ALBUQUERQUE, T.; LOIOLA, M.; NUNES, J. A. C. C.; REISFILHO, J. A.; SAMPAIO, C. L. S.; LEDUC, A. O. C. In situ effects of human disturbances on coral reef-fish assemblage structure: temporary and persisting changes are reflected as a result of intensive tourism. Marine and Freshwater Research, Kingston, v. 66, n. 1, p. 23-32, 2014.

ALONSO, F.; CÁNEPA, M.; MOREIRA, R. G.; PANDOLFI, M. Social and reproductive physiology and behavior of the Neotropical cichlid fish Cichlasoma dimerus under laboratory conditions. Neotropical Ichthyology, Maringá, v. 9, n. 3, p. 559-570, 2011.

BALSHINE, S.; BUSTON P. M. Cooperative behaviour in fishes. In: MAGHAGEN, C.; BRAITHWAITE, V.; FORSGREN, E.; KAPOOR, B. G. (Ed.). Fish behaviour. New Hampshire: Science Publishers, 2008. p. 437-484.

BARLOW, G. W.; BAUER, D. H.; MCKAYE, K. R. A comparison of feeding, spacing, and aggression in color morphs of the Midas cichlid. I. food continuously present. Behaviour, Groningen, v. 54, n. 1-2, p. 72-96, 1975.

BARLOW, G. W.; MCKAYE, K. R. A comparison of feeding, spacing, and aggression in color morphs of the Midas cichlid. II. After 24 hours without food. Behaviour, Groningen, v. 80, n. 3, p. $127-142,1982$.
BESSA, E.; GONÇALVES-DE-FREITAS, E. How does tourist monitoring alter fish behavior in underwater trails? Tourism Management, Oxford, v. 45, p. 253-259, 2014.

BESSA, E.; SILVA, F.; SABINO, J. Impacts of fish tourism. In: BLUMSTEIN, D. T.; GEFFROY, B.; SAMIA, D. S. M.; BESSA, E. (Ed.). Ecotourism's promise and peril: a biological evaluation. 1. ed. Cham: Springer International Publishing, 2017, p. 59-72.

BHUJEL, R. C. A review of strategies for the management of Nile tilapia (Oreochromis niloticus) broodfish in seed production systems, especially hapa-based systems. Aquaculture, Amsterdam, v. 181, n. 1-2, p. 37-59, 2000.

BLUMSTEIN, D. T.; GEFFROY, B.; SAMIA, D. S. M.; BESSA, E. Introduction: ecotourism's promise and peril. In: BLUMSTEIN, D. T.; GEFFROY, B.; SAMIA, D. S. M.; BESSA, E. (Ed.). Ecotourism's promise and peril: a biological evaluation. 1. ed. Cham: Springer International Publishing, 2017. p. 1-8.

BOUlENGER, G. A. Taxonomy of Tilapia rendalli, Boulenger 1897. 1897. Disponível em <http://www.gbif.org/species/2370605>.

BROOKHOUSE, N.; BUCHER, D. J.; ROSE, K.; KERR, I.; GUDGE, S. Impacts, risks and management of fish feeding at Neds Beach, Lord Howe Island Marine Park, Australia: a case study of how a seemingly innocuous activity can become a serious problem. Journal of Ecotourism, New South Wales, v. 12, n. 3, p. 165-181, 2013.

CANDOLIN, U.; VOIGT, H. R. Correlation between male size and territory quality: consequence of male competition or predation susceptibility? Oikos, Copenhagen, v. 95, n. 2, p. 225-230, 2001.

CARVALHO, T. B.; GONÇALVES-DE-FREITAS, E. Sex group composition, social interaction, and metabolism in the fish Nile tilapia. Brazilian Journal of Biology, São Carlos, v. 68, n. 4, p. $807-812,2008$.

CAULTON, M. S. The effect of temperature on routine metabolism in Tilapia rendalli boulenger. Journal of Fish Biology, Malden, v. 11, n. 6, p. 549-553, 1997.

CAVALHEIRO, R. C.; BESSA, E. Sexual selection in the tortoise Chelonoidis denticulata: Dominant partner or healthy partner? Oecologia Australis, Rio de Janeiro, v. 20, n. 3, p. 341 348, 2016.

CHERVINSKI, J. Environmental physiology of tilapias. In: PULlin, R. S. V.; LOWE-MCCONNELL, R. H. (Ed.). The biology and culture of tilapias. $1 \mathrm{ed}$. Manila: International Center for Living Aquatic Resources Management, 1982. p. 119-128.

DA SILVA, F. C.; JÚNIOR, A. L. F.; ARTONI, R. F.; BESSA. E. Impact of feeding fish as a tourist attraction on a coral reef invertivorous fish's diet and growth. Aquatic Conservation: Marine and Freshwater Ecosystems, Malden, doi.org/10.1002/ aqc.2804, 2020.

DE CASTRO, C. S.; RIBEIRO, R. R.; AGOSTINHO, L. M.; SANTOS, A. A. D.; CARMELIN JR, C. A.; CHAN, R. V., NETO, J. F.; AGOSTINHO, C. A. Polyculture of frogs and tilapia in cages with high feeding frequency. Aquacultural Engineering, Jerusalem, v. 61, p. 43-48, 2014.

ELLIS, T.; NORTH, B.; SCOTT, A.; BROMAGE, N.; PORTER, M.; GADD, D. The relationships between stocking density and welfare in farmed rainbow trout. Journal of Fish Biology, v. 61, n. 3, p. 493-531, 2002. 
EWEN, J. G.; WALKER, L.; CANESSA, S.; GROOMBRIDGE, J. J. Improving supplementary feeding in species conservation. Conservation Biology, San Francisco, v. 29, n. 2, p. 341-349, 2015.

FEITOSA, C. V.; CHAVES, L. C. T.; FERREIRA, B. P.; ARAÚJO, M. E. Recreational fish feeding inside Brazilian MPAs: impacts on reef fish community structure. Journal of the Marine Biological Association of the United Kingdom, Cambridge, v. 92, n. 7, p. 1525-1533, 2012.

FELDBERG, E.; PORTO, J. I. R.; BERTOLlO, L. A. C. Chromosomal changes and adaptation of cichlid fishes during evolution. In: VAL, A. L.; KAPPOR, B. G. (Ed.). Fish adaptations. 1 ed. Enfield: Fish Adaptation. Science Publishers, 2003. p. 285308.

FITZPATRICK, R.; ABRANTES, K. G.; SEYMOUR, J.; BARNETT, A. Variation in depth of whitetip reef sharks: does provisioning ecotourism change their behaviour? Coral Reefs, Heidelberg, v. 30, n. 3, p. 569-577, 2011.

GARROD, B.; WILSON, J. C. Nature on the edge? Marine ecotourism in peripheral coastal areas. Journal of Sustainable Tourism, London, v. 12, n. 2, p. 95-120, 2004.

GEFFROY, B.; SAMIA, D. S. M.; BESSA, E.; BLUMSTEIN, D. T. How Nature-Based Tourism Might Increase Prey Vulnerability to Predators. Trends in Ecology and Evolution, Cambridge, v. 30, n. 12, p. 755-765, 2015.

GILL, F. B.; WOLF, L. L. Economics of feeding territoriality in the golden-winged sunbird. Ecology, New York, v. 56, n. 2, p. 333-345, 1975.

GONÇALVES-DE-FREITAS, E.; TERESA, F. B.; GOMES, F. S.; GIAQUINTO, P. C. Effect of water renewal on dominance hierarchy of juvenile Nile tilapia. Applied Animal Behaviour Science, Amsterdam, v. 112, n. 1-2, p. 187-195, 2008.

GONÇALVES-DE-FREITAS, E.; BOLOGNESI, M. C.; GAUY, A. C. DOS S.; BRANDÃO, M. L.; GIAQUINTO, P. C.; FERNANDESCASTILHO, M. Social behavior and welfare in Nile tilapia. Fishes, Basel, v. 4, n. 2, p. 23, 2019.

GRAND, T. C.; GRANT, J. W. A. Spatial predictability of food influences its monopolization and defense by juvenile convict cichlids. Animal Behaviour, St Andrews, v. 47, p. 91-100, 1994.

GRANT, J. W. A. Territoriality. In: GODIN, J. G. L. (Ed.). Behavioural ecology of teleost fishes. Oxford: Oxford University Press, 1997. p. 81-103.

GRANT, J. W. A.; GIRARD, I. L.; BREAU, C.; WEIR, L. K. Influence of food abundance on competitive aggression in juvenile convict cichlids. Animal Behaviour, St Andrews, v. 63, n. 2, p. 323-330, 2002.

HERT, E. Homing and home-site fidelity in rock-dwelling cichlids (Pisces: Teleostei) of Lake Malawi. Environmental Biology of Fishes, New York, v. 33, n. 3, p. 229-237, 1992.

HINSCH, M.; KOMDEUR, J. Defence, intrusion and the evolutionary stability of territoriality. Journal of Theoretical Biology, Pennsylvania, v. 266, n. 4, p. 606-613, 2010.

HOSTIM-SILVA, M.; ANDRADE, A. B.; MACHADO, L. F.; GERHARDINGER, L. C.; DAROS, F. A.; BARREIROS, J. P.; GODOY, E. A. S. Peixes de Costão Rochoso de Santa Catarina. Itajaí: Editora da Universidade do Vale do Itajaí, 2006. 23 p.
ILARRI, M. D. I.; SOUZA, A. T.; MEDEIROS, P. R.; GREMPEL, R. G.; ROSA, I. M. L. Effects of tourist visitation and suppementary feedding on fish assemblage composition on a tropical reef in the Southwestern Atlantic. Neotropical Ichthyology, Maringá, v. 6, n. 4, p. 51-656, 2008.

KEENLEYSIDE, M. H. A. Cichlid fishes: behavior, ecology and evolution. London: Chapman and Hall, 1991. 400 p.

KOKKONEN, E.; MITIKKA, S.; HUUSKONEN, H.; OLIN, M.; RUUHIJÄRVI, J.; VAINIKKA, A. Structural equation models suggest that bottom-up processes override top-down processes in boreal pikeperch (Sander lucioperca) lakes. Freshwater Biology, London, v. 64, n. 5, p. 1054-1063, 2019.

KULLANDER, S. O. A phylogeny and classification of the South American Cichlidae (Teleostei: Perciformes). In: MALABARBA, L. R.; REIS, R. E.; VARI, R. P.; LUCENA, Z. M. S.; LUCENA, C. A. S. (Ed.). Phylogeny and classification of neotropical fishes. Porto Alegre: Edipucrs, 1998. p. 461-498.

LAMBERT, Y.; DUTIL, J. D. Food intake and growth of adult Atlantic cod (Gadus moruhua L.) reared under different conditions of stocking density, feeding frequency and size grading. Aquaculture, Amsterdam, v. 192, n. 2-4, p. 133-147, 2001.

LAROCHE, R. K.; KOCK, A. A.; DILL, L. M.; OOSTHUIZEN, W. $\mathrm{H}$. Effects of provisioning ecotourism activity on the behaviour of white sharks Carcharodon carcharias. Marine Ecology Progress Series, Luhe, v. 338, p. 199-209, 2007.

LAZZARO, X. Feeding convergence in South American and African zooplanktivorous cichlids Geophagus brasiliensis and Tilapia rendalli. Environmental Biology of Fishes, New York, v. 31, n. 3, p. 283-293, 1991.

MAGNHAGEN, C. Sneaking behaviour and nest defence are affected by predation risk in the common goby. Animal Behavior, Bloomington, v. 50, n. 4, p. 1123-1128, 1995.

MAHER, C. R.; LOTT, D. F. A Review of ecological determinants of territoriality within vertebrate species. American Midland Naturalist, Notre Dame, v. 143, n. 1, p. 1-29, 2000.

MARTIN, P.; BATESON, P. Measuring behaviour: an introductory guide. Cambridge: Cambridge University Press, 2007. 171 p.

MEDEIROS, P. R.; GREMPEL, R. G.; SOUZA, A. T.; ILARRI, M. I.; SAMPAIO, C. L. S. Effects of recreational activities on the fish assemblage structure in a northeastern Brazilian reef. PanAmerican Journal of Aquatic Sciences, Rio Grande, v. 2, n. 3, p. 288-300, 2007.

MILAZZO, M.; ANASTASI, I.; WILLIS, T. J. Recreational fish feeding affects coastal fish behavior and increases frequency of predation on damselfish Chromis chromis nests. Marine Ecology Progress Series, Luhe, v. 310, p. 165-172, 2006.

MILAZZO, M.; BADALAMENTI, F.; FERNÁNDEZ, T. V.; CHEMELLO, R. Effects of fish feeding by snorkellers on the density and size distribution of fishes in a Mediterranean marine protected area. Marine Biology, Kiel, v. 146, n. 6, p. 1213-1222, 2005.

O'CONNOR, C. M.; REDDON, A. R.; LIGOCHI, I. Y.; HELLMANN, J. K.; GARVY, K. A.; MARSH-ROLLO, S. E.; HAMILTON, I. M.; BALSHINE, S. Motivation but not body size influences territorial contest dynamics in a wild cichlid fish. Animal Behaviour, St Andrews, v. 107, p. 19-29, 2015. 
PARKER, G. A. Evolutionary stable strategies. In: KREBS, J. R.; DAVIES, N. B. (Ed.). Behavioural ecology: an evolutionary approach. Oxford: Blackwell Scientific Publications, 1984. p. 30-61.

PETRIK, C. M.; STOCK, A. A.; ANDERSEN, K. H.; van DENDEREN, P. D.; WATSON, J. R. Bottom-up drivers of global patterns of demersal, forage, and pelagic fishes. Progress in Oceanography, New Brunswick, v. 176, p. 102124, 2019.

R DEVELOPMENT CORE TEAM. R: a language and environment for statistical computing. 2013. Vienna: R Foundation for Statistical Computing. Disponível em: <https://www.R-project.org/>.

RIBBINK, A. J.; MARSH, A. C.; MARSH, B. A. Nest-building and communal care of young by Tilapia rendalli dumeril (Pisces, Cichlidae) in Lake Malawi. Environmental Biology of Fishes, New York, v. 6, n. 2, p. 219-222, 1981.

RIPLEY, J. L.; LOBEL, P. S. Reproductive behavior of the Lake Malawi cichlid fish, Tramitichromis intermedius. Environmental Biology of Fishes, New York, v. 73, n. 2, p. 171-180, 2005.
ROS, A. F. H.; BECKER, K.; OLIVEIRA, R. F. Aggressive behaviour and energy metabolism in a cichlid fish, Oreaochromis mossambicus. Physiology \& Bahavior, Lisboa, v. 89, n. 2, p. 164180, 2006.

SCHWEDLER, T. E.; JOHNSON, S. K. Responsible care and health maintenance of fish in commercial aquaculture. In: ERICKSON, H. S. (Ed.). Information resources on fish welfare. Vol. 10. Beltsville: Animal Welfare Information Center Bulletin, 2000. p. 91-101.

SERESS, G.; SÁNDOR, K.; EVANS, K. L.; LIKER, A. Food availability limits avian reproduction in the city: an experimental study on great tits Parus major. Journal of Animal Ecology, London, v. 8, n. 7, p. 1570-1580, 2020.

STEMBERGER, R. S.; GILBERT, J. J. Body size, food concentration, and population growth in planktonic rotifers. Ecology, v. 66, n. 4, p. 1151-1159, 1985.

WESTNEAT, M. W.; ALFARO, M. E. Phylogenetic relationships and evolutionary history of the reef fish family Labridae. Molecular Phylogenetics and Evolution, New York, v. 36, n. 2, p. 370-390, 2005.

\section{Appendix 1}

Supplementary Table 1: Aggressive behavior categories observed in the Congo Tilapia and their descriptions.

\begin{tabular}{ll}
\multicolumn{1}{c}{ Category } & \multicolumn{1}{c}{ Description } \\
\hline Bites & A fish approaches its opponent and touches its body with its mouth, biting. \\
\hline Jaw-locking & $\begin{array}{l}\text { Two fish approach one another and simultaneously bite their jaws. They may swim in a } \\
\text { circle while keeping their mouth attached. }\end{array}$ \\
\hline Frontal Attack & It was characterized by head-to-head bumps between two individuals. \\
\hline Attack from behind & $\begin{array}{l}\text { In this behavior the aggressor fish hits the tail of the attacked fish, sometimes nipping on } \\
\text { the fin. }\end{array}$ \\
\hline Side attack & A fish bumps its head on the sides of the attacked individual. \\
\hline Lateral threat & $\begin{array}{l}\text { A fish swims parallel in proximity with the opponent, bristles its fins and opens the } \\
\text { operculum. }\end{array}$ \\
\hline Frontal threat & $\begin{array}{l}\text { Two fish stand face to face without opening the opercula, each one with its mouth open, its } \\
\text { body inclined and head up. There is no physical contact. }\end{array}$ \\
\hline Chasing & $\begin{array}{l}\text { A fish swims towards another, following its trajectory, without physic contact, while the } \\
\text { chased animal moved in escape. }\end{array}$ \\
\hline
\end{tabular}

